\title{
Chemical Toxicity of \\ Uranium Hexafluoride \\ Compared to Acute Effects \\ of Radiation
}

Final Report

Manuscript Completed: January 1991

Date Published: February 1991

Stephen A. McGuire

Division of Regulatory Applications

Office of Nuclear Regulatory Research

U.S. Nuclear Regulatory Commission

Washington, DC 20555

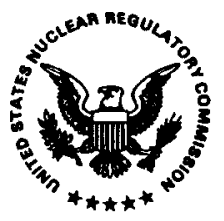

\section{MASTER}




\section{DISCLAIMER}

This report was prepared as an account of work sponsored by an agency of the United States Government. Neither the United States Government nor any agency Thereof, nor any of their employees, makes any warranty, express or implied, or assumes any legal liability or responsibility for the accuracy, completeness, or usefulness of any information, apparatus, product, or process disclosed, or represents that its use would not infringe privately owned rights. Reference herein to any specific commercial product, process, or service by trade name, trademark, manufacturer, or otherwise does not necessarily constitute or imply its endorsement, recommendation, or favoring by the United States Government or any agency thereof. The views and opinions of authors expressed herein do not necessarily state or reflect those of the United States Government or any agency thereof. 


\section{DISCLAIMER}

Portions of this document may be illegible in electronic image products. Images are produced from the best available original document. 
$$
\text { . }
$$ 


\begin{abstract}
The chemical effects from acute exposures to uranium hexafluoride are compared to the nonstochastic effects from acute radiation doses of 25 rems to the whole body and 300 rems to the thyroid. The analysis concludes that an intake of about $10 \mathrm{mg}$ of uranium in soluble form is roughly comparable, in terms of early effects, to an acute whole body dose of 25 rems because both are just below the threshold for significant nonstochastic effects. Similarly, an exposure to hydrogen fluoride at a concentration of $25 \mathrm{mg} / \mathrm{m}^{3}$ for 30 minutes is roughly comparable because there would be no significant nonstochastic effects.
\end{abstract}

ABSTRACT

For times t other than 30 minutes, the concentration $\mathrm{C}$ of hydrogen fluoride considered to have the same effect can be calculated using a quadratic equation: $C=25 \mathrm{mg} / \mathrm{m}^{3}$ $(30 \mathrm{~min} / \mathrm{t})^{0.5}$. The purpose of these analyses is to provide information for developing design and siting guidelines based on chemical toxicity for enrichment plants using uranium hexafluoride. These guidelines are to be similar, in terms of stochastic health effects, to criteria in NRC regulations for nuclear power plants, which are based on radiation doses. 



\section{Contents}

Page

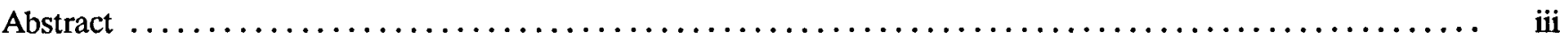

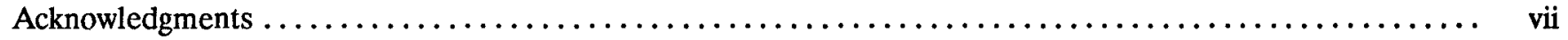

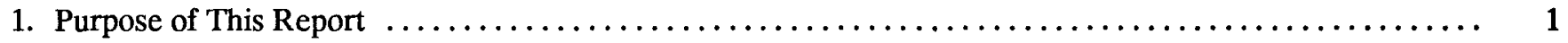

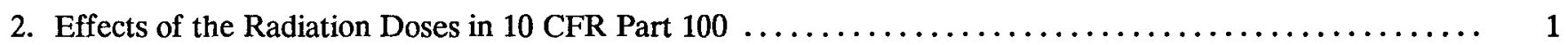

3. Chemical Toxicity of Uranium Hexafluoride and Its Products $\ldots \ldots \ldots \ldots \ldots \ldots \ldots \ldots \ldots \ldots \ldots \ldots$

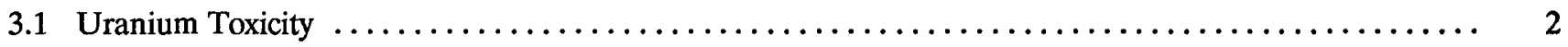

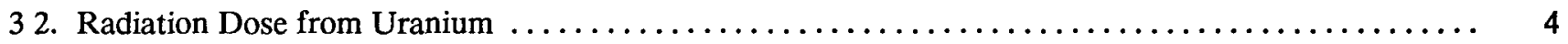

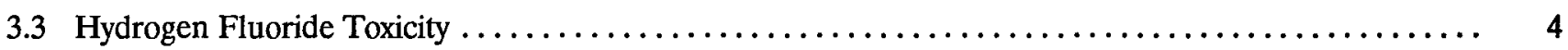

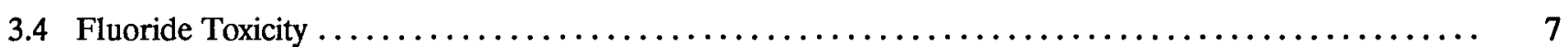

4. Comparison of the Chemical Toxicity of Uranium Hexafluoride With Radiation Doses............ 7

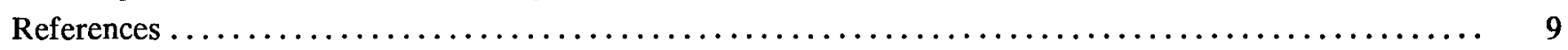

Figure

1 Effects of Exposure of Animals to Hydrofluoric Acid in Air.

\section{Tables}

1 Relative Weights of Uranium Hexafluoride and Its Products $\ldots \ldots \ldots \ldots \ldots \ldots \ldots \ldots \ldots \ldots \ldots \ldots \ldots$

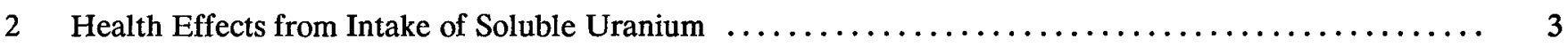

3 Intakes of Uranium of Various Enrichments To Produce 25 -rem Effective Dose Equivalent ........ 4

4 Effects of Inhalation of Hydrogen Flouride on Animals (from Patty, 1962) ............... 5

5 Concentrations of an Exposure to Hydrogen Fluoride Equivalent in Effect to NIOSH IDLH Level ..... 7 



\section{ACKNOWLEDGMENTS}

The contributions of the following people are gratefully acknowledged: Dr. Shlomo Yaniv of the NRC for information and discussions on the health risks of radiation; Barbara Brooks, formerly of the NRC, for information on uranium metabolism and bioassay; Dr. A. Thomas Clark, formerly of the NRC, for many helpful ideas and suggestions; Gary Comfort of the NRC for help with uranium hexafluoride atmospheric dispersion calculations; Peter Loysen and Charles Nilsen of the NRC for many helpful comments and suggestions; Dr. Kathleen Thiessen of Oak Ridge National Laboratory for information on hydrogen fluoride; Howard Ludwig of NIOSH for information on the NIOSH IDLH for hydrogen fluoride; Dr. Vlasta Molak of NIOSH for information on the toxicity of hydrogen fluoride; and Dr. Edward Stein of OSHA for discussions on the OSHA limits on exposure to soluble uranium.

A draft of this report was published for public comment in April 1990, with comments requested by July 15,
1990. The author would like to thank the people who took the time and effort to review and comment on the report.

The people who commented are (in order of receipt): Dr. Paul E. Marrow, University of Rochester Medical Center; Dr. Darrell R. Fisher, Battelle-Pacific Northwest Laboratories; Mr. Jack E. Honey, Allied-Signal Inc.; Ms. Jessie DeerInWater, Native Americans for a Clean Environment; Mr. Marvin Lewis, Philadelphia; Mr. Lee R. Lacey, Sequoyah Fuels Corporation; Dr. Kathleen M. Thiessen, Oak Ridge, TN; Mr. Michael Mariotte, Nuclear Information and Resource Service; Mr. Robert A. Just, Martin Marietta Energy Systems, Inc.; Mr. Peter LeRoy, Duke Engineering and Services, Inc.; Mr. W. Reid Williams, Martin Marietta Energy Systems, Inc.; Mr. J. M. Selby, Battelle-Pacific Northwest Laboratories; Mr. Richard E. Sanderson, U.S. Environmental Protection Agency; and Mr. Philip G. Sewell, U.S. Department of Energy. 


\section{Purpose of This Report}

The purpose of this report is to compare the early chemical effects from acute exposures to uranium hexafluoride with the effects from acute radiation doses of 25 rems to the whole body and 300 rems to the thyroid.

On April 22, 1988, the NRC published in the Federal Register an Advance Notice of Proposed Rulemaking on the regulation of uranium enrichment plants (53 FR 13276). The notice said the NRC was considering adding to its regulations a new 10 CFR Part 76 dealing with uranium enrichment plants.

The notice pointed out that the release of uranium hexafluoride in an accident would be primarily a toxic chemical hazard rather than a radiological hazard. The potential toxic chemical effects to a person exposed to uranium hexafluoride would be more severe than the radiological effects, because uranium is only weakly radioactive and because uranium hexafluoride forms compounds that are readily soluble in the body so they can be transported quickly to sensitive tissues.

The advance notice therefore stated that it would be appropriate to establish design and siting guidelines based on chemical exposure that are roughly equivalent to the radiological guidelines in 10 CFR Part 100, "Reactor Site Criteria." Those guidelines are contained in 10 CFR 100.11, "Determination of Exclusion Area, Low Population Zone, and Population Center Distance." To establish the minimum size of an exclusion area and low population zone, the applicant must show that a specific postulated release, given the containment capability of the plant, would not cause doses to individuals in those areas exceeding certain values. Specifically, the exclusion area must be large enough that "an individual located at any point on its boundary for two hours immediately following onset of the postulated fission product release would not receive a total radiation dose to the whole body in excess of 25 rem or a total radiation dose in excess of 300 rem to the thyroid from iodine exposure." Afootnote to 10 CFR 100.11 states, "The whole body dose of $25 \mathrm{rem}$ referred to above corresponds numerically to the once in a lifetime accidental or emergency dose for radiation workers which, according to NCRP [National Council on Radiation Protection and Measurements] recommendations, may be disregarded in the determination of their radiation exposure status...."

The notice stated, "The staff thus proposes using quantities or concentration values which are at the lower range or average threshold level for chemically toxic effects which, if exceeded, could cause transient or permanent injury." The notice suggested that the corresponding values for a uranium hexafluoride release might be an intake of uranium between 9 and 40 milligrams and exposure to hydrogen fluoride at a peak concentration of 26 milligrams per cubic meter.

On July 8, 1988, the NRC's Office of Nuclear Material Safety and Safeguards (NMSS) requested technical support from the Office of Nuclear Regulatory Research with regard to appropriate values. NMSS requested the determination of values for chemical exposures that, like a 25-rem whole body dose or 300-rem thyroid dose, would not cause significant nonstochastic effects.

Since the time of the original request, the Commission has decided not to proceed with a Part 76 rulemaking at this time (Chilk, 1989). This report provides the support requested for a determination of the equivalency between the chemical toxicity of uranium hexafluoride and radiation dose needed for the review of license applications for uranium enrichment facilities using uranium hexafluoride.

\section{Effects of the Radiation Doses in 10 CFR Part 100}

The radiation doses used in 10 CFR Part 100 are 25 rems to the whole body from external radiation and 300 rems to the thyroid from radioactive iodines. These values were fixed at a dose at which it was believed that no significant observable early effects would occur.

The immediate effects of large acute doses of radiation are nausea, loss of appetite, fatigue, vomiting, diarrhea, and changes in the counts of different types of blood cells. These effects would occur only if a threshold dose were exceeded. None of these effects would be expected in a person exposed to a 25-rem acute dose. A 25-rem whole body dose could cause a temporary reduction in sperm count in males and an elevation in chromosome abnormalities in blood. However, in establishing the dose values in 10 CFR Part 100, these effects were not considered significant in comparison with the acute radiation syndrome effects.

The principal effects of a whole body radiation dose of 25 rems are believed to be stochastic effects (delayed onset, randomly occurring effects), specifically an increased risk of cancer in groups of exposed people and potentially harmful genetic effects in the offspring of people who were irradiated prior to conception of the offspring.

The evidence that an acute dose of 25 rems to the whole body would result in an increased likelihood of cancer is reasonably substantial. The most up-to-date and authoritative estimates of the risks of cancer death are considered to be those in UNSCEAR 1988 and BEIR V, 1990. The data in UNSCEAR 1988 yield a risk from acute radiation doses in the range of 4 to 11 cancer deaths per $10^{4}$ person-rems. The BEIR V estimate is 5.5 to 12 cancer deaths per $10^{4}$ person-rems, quite close to the 
UNSCEAR 1988 estimate. These estimates apply specifically to acute doses between 50 and 600 rems and to the Japanese population specifically. However, the risk estimates for a U.S. population exposed to acute doses of 25 rems should not be greatly different from the UNSCEAR or BEIR risk estimates. Therefore, the risk of cancer death for an average person exposed to 25 rems is considered to be in the range of about 0.01 to 0.03 per person exposed.

For genetic effects, UNSCEAR 1988 estimated 1.2 effects in all successive generations per $10^{4}$ person-rem received before or during the reproductive period. Therefore, the average risk of a radiation-induced genetic disorder in a descendent of an average person exposed to a 25-rem dose is estimated to be about 0.003 .

A 300-rem dose to the thyroid from radioactive iodines is not believed to have any acute effects. Hypothyroidism from radioiodines is considered to have a threshold of 1000 rems (Abrahamson, 1989). The likelihood of death from thyroid cancer is estimated to be in the vicinity of 0.002 (Abrahamson, 1989); in addition, some nonmalignant thyroid nodules could be caused. Based on the available evidence, a 300 -rem thyroid dose is considered to have less risk than a whole body dose of 25 rems.

While a whole body dose of 25 rems or a thyroid dose of 300 rems have a potential for significant long-term effects, they do not produce significant nonstochastic (deterministic) effects.

\section{Chemical Toxicity of Uranium Hexafluoride and Its Products}

When uranium hexafluoride is released in air, it reacts rapidly with water vapor and forms uranium oxyfluoride and hydrogen fluoride:

$$
\mathrm{UF}_{6}+2 \mathrm{H}_{2} \mathrm{O}=\mathrm{UO}_{2} \mathrm{~F}_{2}+4 \mathrm{HF}+\text { heat }
$$

The reaction occurs very rapidly. The chemical reaction releases heat, which may make a plume of these chemical products buoyant and cause it to rise. The chemicals formed by the reaction have three toxic effects: (1) the uranium in the uranyl complex acts as a heavy-metal poison that can affect the kidneys; (2) the hydrogen fluoride is an acid that can cause acid burns on the skin or lungs if it is concentrated; and (3) the fluorides (uranium oxyfluoride and hydrogen fluoride) can cause fluoride poisoning if intakes are large. Each of these effects will be discussed separately below.

One kilogram of $\mathrm{UF}_{6}$ contains $0.68 \mathrm{~kg}$ of uranium and $0.32 \mathrm{~kg}$ of fluoride ions. The reaction with water in the air produces $0.23 \mathrm{~kg}$ of $\mathrm{HF}$, as shown in Table 1 .
Table 1. Relative Weights of Uranium Hexafluoride and Its Products

$\begin{array}{ll}\text { Uranium hexafluoride } & 1.00 \\ \text { Uranium } & 0.68 \\ \text { HF } & 0.23 \\ \text { Fluoride ions } & 0.32\end{array}$

\subsection{Uranium Toxicity}

The most important toxic effect of uranium is damage to the kidneys. High doses of uranium cause tissue damage in the kidneys, leading to functional loss as indicated by failure to resorb urinary protein, glucose, catalase, phosphate, citrate, and creatinine. High doses of uranium also affect the blood vasculature throughout the body. Capillary permeability, blood pressure, and edema may increase, and clotting ability may decrease. Uranium may damage capillary membranes, and it is also known to induce some damage to liver and muscle tissue. Its effects on the nervous system may be similar to those from poisoning by other heavy metals (Fisher 1988).

The toxic effects of uranium were reviewed by a panel of four prominent uranium toxicologists in 1984 (Just, 1984, and Just and Emler, 1984). The toxicologists were Dr. John B. Hursh, Dr. Leonard J. Leach, Dr. Paul E. Morrow, all from the University of Rochester, and Dr. McDonald E. Wrenn from the University of Utah. The panel arrived at a consensus on the toxic effects of uranium. The results presented in Just and Emler are shown in Table 2. In addition, the toxic effects of uranium were reviewed at a meeting sponsored by the NRC in December 1985 (Kathren, 1988). The information by Kathren is consistent with that presented by Just and Emler.

A word of explanation is necessary to explain the meanings of the row labeled "Threshold for transient renal injury or effect" and the row labeled "No effect." The "No effect" row gives levels of uranium at which the expert panel was confident that there would be no observable effects of any type. The row labeled "Threshold for transient renal injury or effect" is the panel's estimate of the level at which effects start to be observed.

The renal injury or effect threshold of $0.058 \mathrm{mg}-\mathrm{U} / \mathrm{kg}$ is the level at which one or more of the chemical components of the urine indicates that there has been some change to some structure within the kidney. The chemical changes at the threshold level have been found to be transient, with the chemical composition of the urine soon returning to normal. Microscopic examination of the kidney would detect no damage several weeks after the exposure. 
Table 2. Health Effects from Intake of Soluble Uranium

\begin{tabular}{|c|c|c|c|}
\hline Health effect & $\begin{array}{l}\text { Uranium } \\
\text { per kg body wt } \\
\text { (mg.U/kg)* }\end{array}$ & $\begin{array}{l}\text { Uranium } \\
(\mathrm{mg}) \text { in } \\
70 \mathrm{~kg} \text { person }\end{array}$ & $\begin{array}{l}\text { Uranium } \\
\text { intake } \\
(\mathrm{mg}) \text { by } \\
70 \mathrm{~kg} \text { person*** }\end{array}$ \\
\hline $50 \%$ lethality & 1.63 & 114 & 230 \\
\hline Threshold for permanent renal damage & $0.3^{* * *}$ & 21 & 40 \\
\hline Threshold for transient renal injury or effect & 0.058 & 4.06 & 8.3 \\
\hline No effect & 0.03 & 2.1 & 4.3 \\
\hline
\end{tabular}

\footnotetext{
"Based on Just and Emler, 1984, except where noted. The number of significant figures result from averaging and do not imply that much precision.

" * Intake is defined as the total amount of material inhaled into the body. It includes material immediately exhaled in addition to material absorbed by the body. For 1 -micron uranium particles in soluble form, about $49 \%$ of the intake will be excreted through the kidneys according to ICRP 30 models (Lessard, 1987, page B-163).

***Based on the conclusions of Wrenn in Just, 1984.
}

At the transient renal injury threshold, the initial loss of reserve capacity, if any, would be small; and that loss would subsequently be reduced by repair. Thus, the longterm consequences to a person subjected to a single intake of uranium at the injury threshold should be minimal.

An intake above 8 or $9 \mathrm{mg}$ produces evidence of transient effects but no evidence of long-term effects. If there are any long-term effects, the effects are too small to be detected.

NRC regulations (10 CFR 20.103(a)(2)) limit acute intakes of soluble uranium by workers on a weekly basis because of its chemical toxicity. The limit for weekly intake is $9.6 \mathrm{mg}$. This limit also applies to a single shortduration intake. NRC believes this intake would cause no harmful effects. The NRC limit was based on the ACGIH TLV (threshold limit values) of $0.2 \mathrm{mg} / \mathrm{m}^{3}$ (ACGIH, 1986 ) inhaled for 40 hours at a breathing rate of $1.2 \mathrm{~m}^{3} / \mathrm{hr}$. Based on the above information, this level is still appropriate.

A recent NRC final rule on emergency preparedness for fuel cycle and other radioactive material licensees (54 FR 14051, April 7, 1989) selected $2 \mathrm{mg}$ of soluble uranium as a potential intake by a person offsite for which emergency plans would have to be prepared. The $2-\mathrm{mg}$ value was selected to be well below the threshold at which effects could be expected to be observed and to have a large margin of safety. Thus, the $2-\mathrm{mg}$ value specified in the rule contains a larger safety margin than appropriate for the comparison in this report.

Of the panel of experts whose views are presented in Just and Emler, 1984, only Wrenn identified a level of uranium expected to cause permanent injury. That level was equivalent to a uranium intake of $40 \mathrm{mg}$. However, microscopic examinations of the kidneys of animals have not found evidence of long-term injury when the animals had been subjected to intakes equivalent to a $40-\mathrm{mg}$ intake by a 70-kg human, nor have long-term biochemical function changes been detected.

Medical examinations of two workers involved in a uranium hexafluoride accident in 1944 revealed no physical findings attributable to uranium intake (Kathren, 1986). The workers were estimated to have had initial lung depositions of 40 to $50 \mathrm{mg}$ of uranium (equivalent to total intakes of 80 to $100 \mathrm{mg}$ of uranium). Thirty-eight years after the accident, no effects of the uranium were found. This suggests that accidental intakes of 80 to $100 \mathrm{mg}$ can occur without significant long-term effects, and therefore suggests that the permanent damage threshold may be higher than the values in Table 2.

Similarly, Fisher et al. (1990) studied the effects of uranium on 31 workers involved in an accident in 1986. None of the workers has sustained any observable health effects from exposure to uranium. The highest intake was estimated at $24 \mathrm{mg}$, and eight of the intakes were in the range of 11 to $24 \mathrm{mg}$. These observed effects do not appear to support a threshold for transient effects as low as $8 \mathrm{mg}$ as shown in Table 2.

The results of two cases of accidental exposure to large amounts of uranium that occurred in China were recently reported (SuLu, 1990). In one case, a worker was exposed to a cloud of $\mathrm{UF}_{4}$ powder. $\mathrm{UF}_{4}$ is generally considered a moderately soluble (Class $\mathrm{W}$ ) compound. The total urinary excretion through day 1065 was calculated to be about $87 \mathrm{mg}$. Kidney function started to show abnormalities on day 78 following the accident. Kidney function gradually returned to normal during the course of a seven-year medical followup. The amount of soluble Class W 1-micron uranium particles that would have to be inhaled to produce a urinary excretion of $87 \mathrm{mg}$ is about $600 \mathrm{mg}$ (Lessard, 1987, page B-340). The reported health effects associated with the uranium urinary excretion of $87 \mathrm{mg}$ are fairly consistent with those in Table 2 , 
although the lack of any observed permanent kidney damage suggests that permanent kidney damage may require more uranium intake than indicated in the table when uranium enters the kidneys gradually.

In the second Chinese case, a man was exposed through the skin to uranyl nitrate and uranium oxide. The uranium oxide would be relatively inert, but the uranyl nitrate would be highly soluble (Class D). Urinary excretion was $130 \mathrm{mg}$ (equivalent to $260-\mathrm{mg}$ intake by inhalation). The patient became ill and showed signs of kidney damage. The signs of kidney damage disappeared by one month after the accident. These results also suggest that the values in Table 2 for permanent kidney damage may be too low.

Based on the discussion above, it is concluded that the NRC's limit of $9.6 \mathrm{mg}$ of soluble uranium for a single acute intake is an intake that would produce in humans either minimal or nondetectable effects, either shortterm or long-term. Thus, an intake of soluble uranium of $9.6 \mathrm{mg}$, rounded off to $10 \mathrm{mg}$, is selected in this report as being comparable to a radiation exposure of 25 rems since neither of these exposure conditions have significant acute effects to the exposed individual.

\subsection{Radiation Dose from Uranium}

The quantity of uranium in soluble form and at various enrichments that must be inhaled to deliver an effective dose equivalent of 25 rems is shown in Table 3. The specific activities in Table 3 were calculated using the following equation (from 10 CFR Part 20, Appendix B, footnote 3 ).

$$
\mathrm{SA}=0.4+0.38 \mathrm{E}+0.0034 \mathrm{E}^{2}
$$

where: $\mathrm{SA}=$ specific activity in microcuries/g, and

$$
\mathbf{E}=\text { enrichment in percent uranium-235. }
$$

The effective dose equivalent in rems per gram of uranium intake was calculated by using a conversion factor of
2.535 rems per microcurie, calculated from the value of $6.85 \times 10-7 \mathrm{~Sv} / \mathrm{Bq}$ given in Eckerman (1988) for uranium-235, solubility Class $D$. The exact values for uranium-234 and uranium-238 are slightly different, but exact values would not affect the results.

Table 3 shows that, even for the highest enrichments, the uranium intake needed to produce a dose of 25 rems is well over $100 \mathrm{mg}$. This compares to an intake of $10 \mathrm{mg}$ of uranium derived as the intake of soluble uranium that would not result in acute effects from chemical toxicity. Therefore, uranium intake for soluble uranium compounds will be limited on the basis of chemical toxicity rather than radiation dose, regardless of enrichment.

\subsection{Hydrogen Fluoride Toxicity}

Moderate exposures to hydrogen fluoride in air can cause smarting of the skin, respiratory irritation, irritation of the conjunctiva (the mucous membrane that lines the inner surface of the eyelids), and pronounced taste. Massive exposure to hydrogen fluoride in air can cause progressive destruction of the bronchial mucous membrane and swelling of lung tissue, which can be fatal.

The toxicity of hydrogen fluoride has been reviewed in Industrial Hygiene and Toxicology (Patty, 1962), in Just and Emler (1984), in "Criteria for a Recommended Standard-Occupational Exposure to Hydrogen Fluoride" (NIOSH, 1976), and in "Summary Review of Health Effects Associated with Hydrogen Fluoride and Related Compounds: Health Issue Assessment" (EPA, 1988).

The effects of inhalation of hydrogen fluoride as determined by experiments on animals are summarized in Table 4.

For many toxic substances, there would be concern about serious injuries at sublethal levels. However, in the case of acute exposures to hydrogen fluoride, if fatality from suffocation caused by edema (swelling) in the lungs does

Table 3. Intakes of Uranium of Various Enrichments To Produce 25-rem Effective Dose Equivalent

\begin{tabular}{cccc}
\hline $\begin{array}{l}\text { Uranium enrichment } \\
(\% \mathbf{U}-235)\end{array}$ & $\begin{array}{l}\text { Specific activity } \\
(\mu \mathrm{Ci} / \mathbf{g})\end{array}$ & $\begin{array}{l}\text { Effective } \\
\text { dose equivalent } \\
\text { per gram U (rem) }\end{array}$ & $\begin{array}{l}\text { Intake to produce } \\
\text { 25-rem effective } \\
\text { dose equivalent (milligrams) }\end{array}$ \\
\hline 0.71 & 0.67 & 1.7 & 14,700 \\
4 & 1.97 & 5.0 & 5,000 \\
20 & 9.36 & 23.7 & 1,060 \\
50 & 27.90 & 70.7 & 353 \\
93 & 65.2 & 165.0 & 151 \\
\hline
\end{tabular}


Table 4. Effects of Inhalation of Hydrogen Fluoride on Animals (from Patty, 1962)

\begin{tabular}{ll}
\hline $\begin{array}{l}\text { HF concentration } \\
\left(\mathbf{m g} / \mathbf{m}^{3}\right)\end{array}$ & Effect \\
\hline 1500 & $\begin{array}{l}\text { Some animals died from a 5-minute exposure. } \\
\text { No animals died from exposures of } 30 \text { minutes or less, } \\
\text { but there was damage to tissue. } \\
1000\end{array}$ \\
$\begin{array}{l}\text { All animals exposed for } 15 \text { minutes or more showed } \\
\text { signs of weakness and ill health. } \\
\text { Could be tolerated for } 5 \text { hours without causing death, } \\
\text { but was a severe irritant. } \\
\text { Rabbits and guinea pigs showed signs of mild irritation, } \\
\text { such as coughing and sneezing, which appeared to lessen } \\
\text { after } 5 \text { to } 15 \text { minutes. } \\
\text { Was tolerated for a total of } 41 \text { hours without a fatality, } \\
\text { although animals subsequently lost weight. }\end{array}$ \\
\hline
\end{tabular}

not occur, the swelling will subside and recovery should be complete. Thus, acute sublethal inhalation of hydrogen fluoride is not expected to have long-term effects.

NIOSH (1985) designates a hydrogen fluoride concentration of $30 \mathrm{ppm}\left(25.4 \mathrm{mg} / \mathrm{m}^{3}\right)$ as immediately dangerous to life or health (IDLH). IDLH is defined as "a maximum concentration from which one could escape within 30 minutes without any escape-impairing symptoms or any irreversible health effects" (NIOSH, 1985).

Documentation on the basis of the NIOSH IDLH (Ludwig, 1990) states that the IDLH is based on the statement of Patty (1962) that $24 \mathrm{mg} / \mathrm{m}^{3}$ (30 ppm) was tolerated by animals for a total of 41 hours without a fatality.

A more recent study of the acute toxicity of hydrogen fluoride estimated the $\mathrm{LC}_{50}$ (lethal concentration to 50 percent of exposed subjects) to be $1670 \mathrm{mg} / \mathrm{m}^{3}$ for a 30 -minute exposure and $1070 \mathrm{mg} / \mathrm{m}^{3}$ for a 60 -minute exposure (Rosenholtz, 1963). Exposures of rats to $6 \%$ of the $\mathrm{LC}_{50}\left(80 \mathrm{mg} / \mathrm{m}^{3}\right.$ for 60 minutes $)$ caused only very mild transient effects-occasional blinking of the eyes and pawing of the nose, but no other signs of toxicity. Therefore, the NIOSH IDLH seems reasonably protective.

The NIOSH IDLH suggests a concentration of hydrogen fluoride that can be tolerated for 30 minutes without escape-impairing symptoms or any irreversible health effects, but it does not tell what concentration could be tolerated for shorter times with the same lack of effect. For substances like uranium that act slowly compared to hydrogen fluoride, the toxic effect is proportional to the total intake, which is the product of concentration times time of exposure (Haber's rule). However, for acute toxicity, ten Berge (1986) found a concentration (C)-time (t) mortality response relationship of irritant and systemically acting vapors and gases in which the response is proportional to $\mathrm{C}^{\mathrm{n}} \mathrm{t}$, where the exponent $\mathrm{n}$ is greater than or equal to one.

The best experimental data on the concentration-timeeffect relationship appear to be those of Machle (1934) and Rosenholtz (1963). Figure 1 is reproduced directly from Machle (1934). The authors have drawn two lines which they considered to represent equal effects. The lines drawn by Machle have the form:

$$
\mathrm{C}=a t^{-b}
$$

Where $\mathrm{C}=$ concentration of $\mathrm{HF}$

$\mathrm{a}=\mathrm{a}$ constant

$\mathrm{t}=$ time exposed to $\mathrm{HF}$

b $=$ exponent

This equation is algebraically equivalent to ten Berge's equation. From the slope of the lines in Figure 1, $\mathrm{b}=0.58$.

If one wanted to adopt a more conservative approach and select a value of $b$ that would yield a flatter curve (lower concentrations for shorter exposure times), the value of $b$ could be rounded down to $b=0.5$. The equation would then express a quadratic relationship in which response is proportional to concentration squared times time of exposure. Thus, for times $t$ (in $\mathrm{min}$ ) shorter than 30 minutes, the concentration $C$ equivalent to the IDLH value of 25 $\mathrm{mg} / \mathrm{m}^{3}$ is given by this relationship:

$$
\mathrm{C}=25 \mathrm{mg} / \mathrm{m}^{3}(30 \mathrm{~min} / \mathrm{t})^{1 / 2}
$$




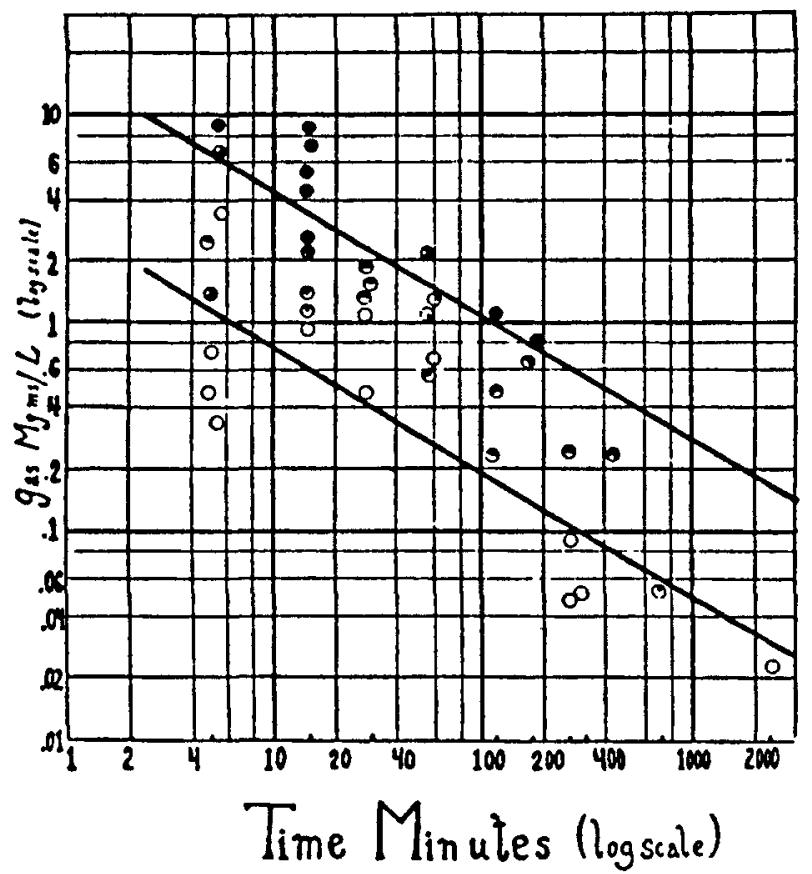

Figure 1. Effects of exposure of animals to hydrofluoric acid in air. - Death all animals. - Proportional deaths in group. $\bigcirc$ - No deaths in group. From Machle, 1934. Lines were drawn by authors to show equal effects.

Table 5 shows concentrations calculated from this equation.

The values in Table 5 are in reasonable agreement with the observations of Machle (1934) that a concentration of $100 \mathrm{mg} / \mathrm{m}^{3}$ could be tolerated by human volunteers for only a little more than a minute.

The values are also in reasonable agreement with the emergency response planning guidelines for 60-minute exposures to hydrogen fluoride developed by the American Industrial Hygiene Association (AIHA, 1988). The AIHA Emergency Response Planning Guidelines are defined as:

ERPG-1 The maximum airborne concentration below which it is believed that nearly all individuals could be exposed for up to one hour without experiencing other than mild, transient adverse health effects or without perceiving a clearly defined objectionable odor.

ERPG-2 The maximum airborne concentration below which it is believed that nearly all individuals could be exposed for up to one hour without experiencing or developing irreversible or other serious health effects or symptoms which could impair an individual's ability to take protective action.
ERPG-3 The maximum airborne concentration below which it is believed that nearly all individuals could be exposed for up to one hour without experiencing or developing life-threatening health effects.

The ERPG-1 value for HF is $4.1 \mathrm{mg} / \mathrm{m}^{3}$, the ERPG-2 value is $16.4 \mathrm{mg} / \mathrm{m}^{3}$, and the ERPG-3 value is $41 \mathrm{mg} / \mathrm{m}^{3}$.

The ERPG-2 level appears to correspond most closely to the NIOSH IDLH. It corresponds to a level that would cause irritation and have an objectionable odor but no serious transient effects and no permanent effects. The ERPG-2 level of $16.4 \mathrm{mg} / \mathrm{m}^{3}$ for 60 minutes is in good agreement with Table 5 .

The concentration-time-response relationship for hydrogen fluoride has also been studied by ten Berge (1986), based primarily on the data of Machle (1934) and using a sophisticated statistical technique. Ten Berge also concluded that for hydrogen fluoride exposure the effect is proportional to $\mathrm{C}^{2} \mathrm{t}$.

The same quadratic relationship has been derived by Turner and Fairhurst (1990) based largely on the experiments of Rosenholtz (1963). Turner and Fairhurst developed the concept of "toxic load" as a measure of the 
Table 5. Concentrations of an Exposure to Hydrogen Fluoride Equivalent

in Effect to NIOSH IDLH Level

\begin{tabular}{ccr}
\hline $\begin{array}{l}\text { Exposure time } \\
(\mathbf{m i n})\end{array}$ & $\begin{array}{l}\text { Concentration equivalent } \\
\text { to IDLH }\left(\mathbf{m g} / \mathbf{m}^{3}\right)\end{array}$ & $\begin{array}{c}\text { Exposure } \\
\left(\mathbf{m g}-\mathbf{m i n} / \mathbf{m}^{3}\right)\end{array}$ \\
\hline 1 & 137 & 137 \\
2 & 97 & 194 \\
5 & 61 & 306 \\
10 & 43 & 433 \\
15 & 35 & 530 \\
30 & 25 & 750 \\
60 & 17.7 & 1060 \\
\hline
\end{tabular}

impact of hydrogen fluoride. They also found a quadratic relationship:

$$
\text { toxic load }=\mathrm{C}^{2} \mathrm{t}
$$

They then determined a "dangerous toxic load" (DTL), which is a level below the threshold for human fatality. From experimental data, they determined that the mouse was the animal most susceptible to damage from hydrogen fluoride. For the mouse, they determined that a toxic load of $2,400,000 \mathrm{ppm}^{2}-\mathrm{min}\left[1,720,000\left(\mathrm{mg} / \mathrm{m}^{3}\right)^{2}-\mathrm{min}\right]$ would be below the threshold of lethality. Thus, for example, a concentration of $240 \mathrm{mg} / \mathrm{m}^{3}$ for 30 minutes would produce a dangerous toxic load.

Turner and Fairhurst's DTL is a factor of 8 higher than the NIOSH IDLH. The difference occurs because they are based on different criteria (fatality threshold vs. no escape-impairing symptoms). However, Turner and Fairhurst support the use of a quadratic relationship between concentration and effect.

To summarize, in selecting a level for no significant effect, short term or long term, it was decided to use as a basis the NIOSH IDLH level of $25 \mathrm{mg} / \mathrm{m}^{3}$ for 30 minutes. If the exposure time $t$ has a duration other than $30 \mathrm{~min}$ utes, the concentration $\mathrm{C}$ can be calculated by the equation, $\mathrm{C}=25 \mathrm{mg} / \mathrm{m}^{3}(30 \mathrm{~min} / \mathrm{t})^{0.5}$. These concentrations would be irritating and would have an objectionable odor, but would not produce any escape-impairing symptoms or any permanent effects.

\subsection{Fluoride Toxicity}

This section discusses the toxicity of the fluoride ion $\left(\mathrm{F}^{-}\right)$. The fluoride ions can also have harmful effects and can cause systemic fluoride poisoning, even death from cardiac or respiratory failure. The fluoride ions can penetrate the skin, destroy tissue under the skin, and cause inhibition of vital enzymes and dangerous disturbances in metabolism (e.g., calcium and carbohydrate balance) by chemical binding of the fluoride ion to calcium or magne- sium ions. However, subjects who have died of massive hydrogen fluoride inhalation do not seem to die of metabolic fluoride ion effects, but of the consequences of severe acid burns to the respiratory tract (Braun, 1984).

A lethal dose from acute fluoride poisoning is estimated to be an absorption of 32 to $64 \mathrm{mg}$ of fluoride per kilogram of body weight (EPA, 1988). A safe or no-effect absorption is considered to be 8 to $16 \mathrm{mg}$ per kilogram of body weight. In a 70-kg person, the no-effect absorption would be about 500 to $1000 \mathrm{mg}$. Intakes of this magnitude would be associated with lethal quantities of both uranium and hydrogen fluoride. Thus, for all practical purposes, acute effects of fluoride toxicity from a uranium hexafluoride release can be ignored. There has been some research that indicates that fluorides may be carcinogenic. A recent animal study found more cancers in rats given fluorides than in controls. No effect was observed in mice, but in another study, animal and human tissues maintained in test tubes and treated with fluoride were subjected to genetic tests to indicate possible cancer risks. All tests were negative.

Overall, there is not yet a scientific consensus on whether fluorides are carcinogenic. This issue, however, is not directly relevant to this report, because the basis for comparison of radiation effects with chemical effects is that there be no observable acute effects.

In summary, the acute effects of fluoride ions by themselves are unimportant relative to the acute effects of either the uranium or the hydrogen fluoride.

\section{Comparison of the Chemical Toxicity of Uranium Hexafluoride With Radiation Doses}

The Advance Notice of Proposed Rulemaking for uranium enrichment facilities proposed "using quantities or concentration values [for toxic chemicals] which are at the lower range or average threshold level for chemically 
toxic effects which, if exceeded, could cause transient or permanent injury."

As can be seen from the previous sections, the effects of radiation, soluble uranium, and hydrogen fluoride are different. However, it is possible to identify uranium intakes and hydrogen fluoride exposures that will not cause transient or permanent injury.

The health effects from soluble uranium were reviewed in Section 3.1 and summarized in Table 2. Just and Emler (1984) selected an intake of $8 \mathrm{mg}$ of uranium to be near the threshold for mild transient effects that have no known long-term effects. NRC regulations permit intakes of up to $9.6 \mathrm{mg}$ of soluble uranium for workers with the assumption of no significant adverse effects. An intake of soluble uranium with no significant detectable health effects, transient or permanent, appears to be about $10 \mathrm{mg}$ in round numbers.

The health effects of hydrogen fluoride were reviewed in Section 3.3 and summarized in Table 4. From the information presented, it can be seen that exposures to HF of $25 \mathrm{mg} / \mathrm{m}^{3}$ for 30 minutes would not cause "any escapeimpairing symptoms or any irreversible health effects." This exposure should not have any significant adverse health effects and would not cause transient or permanent injury. For times other than 30 minutes, the concentration of hydrogen fluoride considered to have an equivalent effect can be calculated from the following equation:

$$
\mathrm{C}=25 \mathrm{mg} / \mathrm{m}^{3}(30 \mathrm{~min} / \mathrm{t})^{0.5}
$$

The values developed in this report for uranium intake and hydrogen fluoride exposure comparable to a 25-rem whole body dose are values that can be used in the design of a plant and the evaluation of consequences in the event of certain specific postulated accidents. The values are neither acceptable exposures nor limits on exposures.

The values are not "acceptable" any more than a 25 -rem whole body radiation dose is an "acceptable" dose. The values are also not limits. The concept of a limit implies that one has a choice and can control the exposure. The actual situation during an accident is that neither the situation nor the exposure that will result can be controlled.

One possible use of the values is to establish the size of an exclusion area around the facility. To do this, a design basis accident must be determined. The design basis accident is a hypothetical accident that a facility must be designed to cope with, but it is usually not the worst possible accident. The design basis accident postulates certain equipment failures, but generally also assumes that other engineered safety systems will function. Another possible use of these values would be to identify processing equipment for which there should be a high degree of protection against a significant release of uranium hexafluoride. 


\section{REFERENCES}

Abrahamson, S., et al., "Health Effects Models for Nuclear Power Plant Accident Consequence Analysis," NRC Report NUREG/CR-4214, Revision 1, Part II, 1989.

American Conference of Governmental Industrial Hygienists, "TLV's: Threshold Limit Values for Chemical Substances in the Work Environment Adopted by ACGIH with Intended Changes for 1986-87," Cincinnati, Ohio, 1986.

American Industrial Hygiene Association, "Emergency Response Planning Guidelines-Hydrogen Fluoride," Akron, Ohio, 1988.

"BEIR V," Committee on the Biological Effects of Ionizing Radiations, National Research Council, Health Effects of Exposure to Low Levels of Ionizing Radiation: BEIR V, National Academy Press, Washington, DC, 1990.

Braun, J., H. Stross, and A. Zober, "Intoxication Following the Inhalation of Hydrogen Fluoride," Archives of Toxicology, Volume 56, pp. 50-54, 1984.

Chilk, Samuel J., Secretary of the Commission, Memorandum to Victor Stello, Jr., Executive Director for Operations, "Staff Requirements Memo Re Proposed Rule," May 9, 1989. Available in the NRC Public Document Room.

Eckerman, Keith F., Anthony B. Wolbarst, and Allan C. B. Richardson, Limiting Values of Radionuclide Intake and Air Concentration and Dose Conversion Factors for Inhalation, Submersion, and Ingestion, Federal Guidance Report No. 11, EPA Report EPA-520/1-88-020, 1988.

Environmental Protection Agency, "Summary Review of Health Effects Associated with Hydrogen Fluoride and Related Compounds: Health Issue Assessment," EPA Report EPA-600/8-89-002F, 1988.

Fisher, D. R., "Uranium," in Handbook on the Toxicity of Inorganic Compounds, Chapter 68, pp. 739-748, H. G. Seiler and H. Sigel, editors, Marcel Dekker, Inc., New York, 1988.

Fisher, D. R., M. J. Swint, and R. L. Kathren, "Evaluation of Health Effects in Sequoyah Fuels Corporation (SFC) Workers from Accidental Exposure to Uranium Hexafluoride," NRC Report NUREG/CR-5566 (PNL-7328), May 1990.

International Commission on Radiological Protection, "Limits for Intakes of Radionuclides by Workers," ICRP Publication 30, Pergamon Press, 1979.
Just, R. A., "Report on Toxicological Studies Concerning Exposures to $\mathrm{UF}_{6}$ and $\mathrm{UF}_{6}$ Hydrolysis Products," DOE Report K/D-5573, Revision 1, 1984.

Just, R. A., and V. S. Emler, "Generic Report on Health Effects for the U.S. Gaseous Diffusion Plants," DOE Report K/D-5050, Section VIII, Part 1, 1984.

Kathren, Ronald L., and Robert H. Moore, "Acute Accidental Inhalation of U: A 38-Year Follow-Up," Health Physics, 51, 609-619, 1986.

Kathren, R. L., and J. R. Weber, Editors, "Ultrasensitive Techniques for Measurement of Uranium in Biological Samples and the Nephrotoxicity of Uranium," NRC Report NUREG/CP-0093, 1988.

Lessard, Edward T., et al., "Interpretation of Bioassay Measurements," NRC Report NUREG/CR-4884 (BNL-NUREG-52063), 1987.

Ludwig, Howard R., editor, "Documentation for Immediately Dangerous to Life or Health Concentrations," Draft, National Institute for Occupational Safety and Health, Cincinnati, Ohio, July 1990. (Copies may be obtained from H. R. Ludwig, NIOSH, 4676 Columbia Parkway, Cincinnati, Ohio 45226.)

Machle, W., et al., "The Effects of the Inhalation of Hydrogen Fluoride. I. The Response Following Exposure to High Concentrations," J. Ind. Hygiene Toxicology, 16, 129-145, 1934.

NIOSH, Criteria for a Recommended Standard-Occupational Exposure to Hydrogen Fluoride, HEW Publication NIOSH 76-143, 1976.

NIOSH, "NIOSH Pocket Guide to Chemical Hazards," HHS Publication NIOSH 85-114, 1985.

Patty, Frank A., Editor, Industrial Hygiene and Toxicology, Volume II, Second Revised Edition, John Wiley \& Sons, New York, 1962.

Rosenholtz, M.J., et al., "A Toxicopathological Study in Animals After Brief Single Exposures to Hydrogen Fluoride," Am. Ind. Hyg. Assoc. J., 24, 253-261, 1963.

SuLu and Fu-Yao Zhao, "Nephrotoxic Limit and Annual Limit on Intake for Natural U," Health Physics, 58, 619-23, 1990.

ten Berge, W.F., A. Zwart, and L. M. Appelman, "Concentration-Time Mortality Response Relationship of Irritant and Systemically Acting Vapours and Gases," $J$. Haz. Mat., 13, 301-309, 1986. 
Turner, R.M., and S. Fairhurst, "Toxicology of Substances in Relation to Major Hazards," Her Majesty's Stationery Office, London, 1990. (Available for inspection or for copying for a fee at the NRC Public Document Room, 2120 L Street NW., Washington, DC.)
United Nations Scientific Committee on the Effects of Atomic Radiation (UNSCEAR), Sources, Effects and Risks of Ionizing Radiation, pp. 387, 493-494, United Nations, New York, 1988. 